TRAMES, 2009, 13(63/58), 3, 248-264

\title{
UNDISCOVERED AVENUES? \\ ESTONIAN CIVIL SOCIETY ORGANISATIONS AS AGENTS OF EUROPEANISATION
}

\author{
Kristian L. Nielsen, Eiki Berg, Gulnara Roll
}

University of Tartu

\begin{abstract}
Within neoliberal approaches to the study of International Relations there is a consensus that nongovernmental actors and their potential impact need to be studied more. This article examines how Estonian civil society organisations are acting as agents in the general Europeanisation processes. The framework within which they operate, the European Neighbourhood Policy and the EU-Russia Strategic Partnership, are both in theory open to participation by the third sector. The EU's foreign policy, being built up to such a large degree around notions of soft power, should also lend itself easily to the kinds of bottom-up approaches to spreading its influence, which civil society can help effecting. The empirical work shows, however, that due to both institutional and procedural obstacles, this sort of cooperation is not happening to a great extent, or is at least significantly hampered. On key issues and in terms of priorities the agendas of civil society organisations and traditional state actors also tend to diverge, with the former eager to pursue more normative charged policies, and the latter taking a more traditional approach. The state of civil society in the former Soviet Union also makes this style of policy more difficult. Thus the central argument of this article is that while civil society organisations do offer interesting avenues to explore, the EU has been far too unappreciative of the needs of civil society organisations, and has therefore not been able to fully utilise the resources they could potentially provide.
\end{abstract}

DOI: $10.3176 /$ tr.2009.3.04

Keywords: Europeanisation, foreign policy agency, CSO, European neighbourhood policy

\section{Introduction}

Since EU accession in 2004, Estonia has been working hard to adapt its foreign policy to the new realities of membership. This has been the case not only for the activities of the state institutions, like the Ministry of Foreign Affairs, but also for the growing civil society sector, which has also found itself operating in a new context. For Estonia relations with Russia have always been a major factor, and 
not surprisingly this relationship has been carried over into the new context that EU membership creates, not least given the importance attached to EU-Russia relations by many of the older EU member states.

International Relations have generally focused on the actions of states vis-à-vis other states. Likewise, the study of the foreign relations of the European Union also tends to focus on its dealings with the governments of its interlocutors, how the member states are using the EU as a vehicle for their national interests, and whether one can consider the EU as being to some extent an autonomous actor with its own interests. This applies to many studies of the EU's security strategies in the past as well as to the current strategy towards the countries bordering the union, namely the European Neighbourhood Policy (ENP). Such state-centric approaches may be justified since in many of its foreign relations the EU does indeed act in a manner not entirely dissimilar to that of nation states, especially given that increasingly the 27 member states are willing to speak with one voice on a range of international issues. In this view the objectives pursued under the ENP can be seen as part of an overarching geopolitical strategy aiming to bring countries closer to the European 'norm' and to strengthen Europe's influence in these countries, thus ultimately trying to enhance its own security (Alibioni 2005, Marchetti 2006).

The state-centric approaches go a long way to explain the objectives of the EU and the state level interactions. At the same time, it is worth exploring some of the processes involved and looking beyond the traditional state-to-state forms of foreign policy conduct. This paper adopts a broadly neo-liberal point of view to look beyond pure state-centrism, while acknowledging the value of such approaches, to ask what role other actors, such as civil society organisations can play in foreign policy, in this case specifically those of the EU. In doing so, this paper looks at what roles Estonian civil society organisations (CSOs) have played in pursuing the EU's Europeanisation ${ }^{1}$ goals under the European Neighbourhood Policy and the EU-Russia Strategic Partnership.

Within the theory of complex interdependence Robert Keohane and Joseph Nye (1977), move away from seeing states as simple unitary actors. Rather this theory holds that in the modern world several more actors are playing a role in foreign policy, and that the international scene has become much more fluid as a result. These developments do not remove the importance of the traditional role of the state, but they do muddy the picture significantly in a number of important ways, as corporate interests and civil society organisations (CSOs) are coming increasingly into focus. At the same time more policy areas have gained prominence in international politics; environmental matters, democracy and human rights, development aid among others. The increased fluidity of the international scene, which has partly resulted from the processes of globalisation have opened up for a

1 According to a commonly accepted definition, Europeanisation refers to the construction, diffusion and institutionalization of formal and informal rules, procedures, policies and norms which are first defined and consolidated at the European level and then incorporated in domestic institutions, policies, identities, and discourses (Radaelli 2000). 
number of alternative styles of foreign policy making and implementation, which can to some extent by-pass the traditional state-based forms of diplomacy. In many of its initiatives under the ENP, the EU has tried to reach out to and support, and in effect coopt, CSOs inside the existing member states and in neighbouring countries in order to further its overall policy aims. For example, in the recent communication to the Council and the European Parliament, the Commission underlines the need "to allow appropriate participation by civil society representatives as stakeholders in the reform process, whether in the preparation of legislation, the monitoring of its implementation or in developing national or regional initiatives related to the ENP" (COM (2006)726).

What this article will attempt is to show how Estonian CSOs are acting as agents of Europeanisation through their activities with Russian counterparts in the framework of general EU-Russia relations. It will do so by firstly laying out some basic ideas of the role of CSOs in international relations, and how they can act as agents to promote a foreign policy agenda, bypassing in the process the traditional channels of foreign policy making. It will then proceed to sketch out the general EU policy context towards Russia, in which the CSOs operate, followed by some general observations on how CSOs can act in pursuit or support of the EU's agenda, as well some of the difficulties inherent in such an approach. Lastly some examples, both positive and negative, will be given of the extent to which Estonian and Russian CSOs have been able to cooperate along the lines of the EU's general Europeanisation agenda, which suggest that although the potential is there, pursuing such a policy is not at all plain sailing.

\section{Civil society organisations as actors in foreign policy}

That CSOs have gained in significance in International Relations in recent decades owes much to the general processes of globalisation and developments in communication technologies. Contacts with supporters inside countries have become far easier and more efficient, and communications across borders with like-minded organisations, or umbrella organisations, have become commonplace and outside of state control. Whereas most communication channels were just a few decades ago almost entirely within the control of the states, there are now so many channels open that blocking them is close to impossible. The implication of this is that groups other than state actors now have the opportunity to vie for attention, and to maintain their own contacts.

The biggest asset any CSO holds is its ability to influence public opinion in the country in which it operates. Their expertise in certain fields and their dedicated supporters provide a platform from which they can advocate and create a demand for specific policies that meet their concerns (Ringius 1997). At the same time the detachment from the normal political processes - standing for election, developing broad policy programmes etc. - give the CSOs a special status, as they can present themselves as being above normal politics. This is a privilege which neither 
national governments nor intergovernmental organisations enjoy (Warleigh 2001). What effect this can have has been most clearly shown, but not exclusively, in the environmental field, where transnational coalitions between non-state actors have frequently been formed on issues of common concern (Ringius 1997). A major example of CSOs acting in an advocacy capacity, and helping to shape both public opinion as well as government policy, is the role of Norwegian NGOs on the issue of banning landmines (Sending and Neumann 2006). Also Human Rights NGOs, both national and international, can frequently play a major role in agenda-setting.

For state-centric approaches to the study of IR, other actors such as CSOs barely figure as study objects. Their activities use little of the traditional power resources that IR theorists, especially those of a Realist persuasion, consider essential. However, in some very important respect it is the very things that set them most apart from traditional state actors that make them most attractive in their foreign policy related activities. In a number of ways CSOs can potentially influence policy and help achieve outcomes that might otherwise have been difficult through traditional channels. In her study on promoting democracy in the EU's Eastern Neighbourhood, Kristi Raik (2006) demonstrates how several western countries channel some of their external aid through foundations that function as quasi-governmental actors. These are publicly funded and to some extent supervised by the donor government. What makes their activities peculiar is the fact that although they are often in line with their home country's official foreign policy, their formal independence is nonetheless recognised by target countries in spite of this dependency. Democracy promotion is therefore taking place not just on an interstate, but also on a grass-root level - a local scale where foundations or CSO's are able to work more effectively than governments, and can thus really bring added value to official policy (Raik 2006). It is also a form of activity which it is difficult to block entirely, especially in the modern world. If one given state tries to block foreign exchange at one level, interaction can simply switch to another level, making at least a certain amount of openness between societies almost inevitable (Filtenborg et. al. 2002).

On the one hand, such developments may to some degree have undermined the traditional authority of the state. Indeed, a very legitimate concern existing about the activities of CSOs is that they lack clear mandates like that enjoyed by democratic governments. On the other hand, they have also opened up for new approaches from outside powers pursuing certain agendas. In other words, connecting with and supporting CSOs in other countries, or supporting own CSOs who then interact with similar groupings in the target country, may allow states to pursue a 'bottom-up' approach to achieving foreign policy objectives. This has been the case in development policy, where donor countries often rely on CSOs to implement various policies. The status of CSOs as not linked to political parties or governments often makes them acceptable to local people for carrying out such projects (Warleigh 2001). Thus CSOs work as 'active partners' with governments, implementing their policies, but officially remaining independent. More problematic than this kind of 'benign interference', is the possibility that CSOs without much 
local base, but primarily existing on outside funding can hijack agendas; again a very legitimate concern for national governments, which should not be dismissed lightly as mere propaganda.

Another problem that can occur with this kind of cooperation, though, is that the agendas of CSOs and governments are not always identical, and that CSOs can at times be hard to control. This poses a problem for the donors, whether states or international organisations. Working relationships can be strained, priorities may differ, and mutual understanding may not always be optimal. CSOs focused on particular issues are not always very understanding of the 'broader considerations' other actors may be taking. The EU found that many of the NGOs it had been working with during the ongoing Doha Round were among its sharpest critics when negotiations broke down in Cancun in 2003, largely over the EU's insistence on continuing its harmful protectionist practices in the field of the Common Agricultural Policy (Michalski 2005).

That states often remain in charge of the purse strings for projects is another contentious aspect which can result in friction. More problematic from the point of view of CSOs is that in order to meet the often very strict requirements for getting funding, grants and subsidies, they must submit to a high degree of control from the states or IGOs that they cooperate with. This can make the formulation of independent stances harder, blur the profile of the CSO, and thus ultimately undermine the very thing - their independence - that made a CSO attractive in the first place (Warleigh 2001).

\section{Wider Europe and the EU-Russia strategic partnership}

The concept of a 'Wider Europe' of 2003, which in turn led to the formulation of the European Neighbourhood Policy in 2004, marked yet another step in the gradual emergence of the EU as a genuine actor in foreign policy. The stated aim was to create 'A Ring of Friends' among the countries bordering the EU, but having no immediate prospect of membership (COM (2004) 373). Put another way, the ENP was to act as an alternative to the EU's Enlargement Policy, which, in spite of having in the past been an extraordinarily successful foreign policy tool, was not easily applicable to the new neighbours (Dannreuther 2006). Instead, the idea behind the ENP is to export the values and workings of the EU, drawing the targeted countries closer and achieving a measure of integration without taking the full step towards actual membership. The ENP thus entails a process of 'Europeanisation', as the target countries will ideally move towards the EU norms in a variety of fields such as market economy, law and order, respect for human rights and democratisation. The policy is built around action plans - under which the partner country agrees to adopt parts of the EU's acquis - and the tested principle of conditionality; 'carrots' or rewards - in the shape of further integrative measures becoming available - being offered for good performance in implementation, while withholding of such rewards are implicitly threatened for non-compliance. 
The ENP does not stand alone as a strategy formulation of the EU. The European Security Strategy (ESS), published in December 2003, highlighted a number of inter-related threats to the security of the EU, the most important of which were: Terrorism, Organised Crime, Regional Conflicts, Failed States, and Proliferation of Weapons of Mass Destruction. While the last of these clearly falls completely outside the scope of the ENP, the others can in various ways be seen within this broader framework. The ESS stresses the EU's preference for 'preventive engagement' in order to deal with these problems (Toje 2005). The ENP itself stands as an example of the EU's preference for milieu shaping policies, through institutionalising cooperation and building processes, rather than traditional possession goals (Nielsen 2008). Thus the ENP envisages enhanced cooperation with these states, pulling them closer to the EU in order to minimise the risk of any of these problems reaching an acute level in the first place.

While the ENP is a general policy framework targeting a number of countries, Russia is a special case. Not content to be considered on the same level as Georgia or Algeria, Russia instead proposed a bilateral framework called the Strategic Partnership. Instead of drawing up action plans, the EU and Russia negotiate on the creation of 'four common spaces' (Nielsen 2007). Although the labelling is somewhat different between the two policy programmes, much of the policy substance is the same. Furthermore, the European Neighbourhood Policy Instrument (ENPI) is also the funding source for projects undertaken within the context of the Strategic Partnership. A major difference in form between the two programmes is that conditionality, at Russia's insistence, does not apply in the bilateral framework.

In formulating strategies such as the ENP and the Strategic Partnership, the EU is attempting to utilise what Joseph Nye (2005) calls 'soft power'. This term refers to the ability to attract and entice other states to want the same things as one self, relying on persuasion and example rather than simple coercion. What makes the EU attractive and gives it soft power is its values and norms, its single market, cultural and educational exchange. It is because the EU is considered positively in partner countries that these are seeking to achieve a measure of integration in order to gain access to what the EU holds. Related to this line of thought is also Ian Manners' famous concept of the EU as a 'normative power', able to define what is considered 'normal' in international relations (Manners 2002). Using this ability the EU has been able to impart to the other countries its vision of the good world. What gives the EU this power is exactly that it is different from other actors - "the EU exerts influence not by what it does or says, but by what it is", as Manners (ibid.) famously put it - and that it embodies a higher normative ethic (Manners 2008). Given the many areas involved in the general Europeanisation framework the two policies sketched here can together be considered a deliberate strategy for diffusion of the EU's norms and values to other countries.

Europeanisation is about value diffusion, and shaping of identities. Particularly important in the EU's pursuit of Europeanisation is the effective sharing of certain values. Thus while the means being employed are primarily economic, other 
important areas included in the ENP 'Action Plans', and to a lesser extent in the Strategic Partnership, are democratisation and strengthening of the respect for human rights. Thus it is the EU's normative values which form the basis for cooperation, and, for some scholars, this gives credence to claims of a higher normative ethic of the EU. At the same time, though, the very insertion of conditionalities is essentially coercive, and thus, arguably, undermines the claim of the EU being merely a 'normative power', in that it states demands and threatens withholding of privileges and access in case of non-compliance (Hyde-Price 2006). Either way, however, the ENP and the Strategic Partnership are both clear attempts by the EU to Europeanise neighbouring countries, and the established policy frameworks do offer the EU the possibility for influencing the internal policies and politics of the neighbouring states in various spheres using the most effective means at its disposal.

The full impact of these policies toward the neighbouring countries is still hard to gauge given their newness. Yet one particular feature already looks clear: New connotations of old terms compel policy-makers to devise strategies suited for the changed realities and consistent with the evolved thinking. Walters (2004) has shown how the traditional Westphalian concept of a border as a line on the ground is being challenged by new approaches that define borders in terms of networks or zones of interaction. Although the EU external border is a geographically defined fixed line it may signify also the 'reach' of the EU's influence and external governance. In order to gain control over policy developments in the immediate neighbourhood, borders are important instruments in controlling inclusion and exclusion in line with the logic of conditionality (Lavenex 2004). How blurred the borders will eventually become depends on how successful the ENP will be drawing the partner states closer to the EU policymaking process and making them adapt to EU norms without extending the actual prospect of membership (Filtenborg et. al. 2002). Potentially - and that is an implicit ambition of the ENP the division between those inside and outside of the EU will be lessened so as to avoid new dividing lines in Europe.

\section{Civil society organisations as agents of Europeanisation}

In the new patterns of network governance that are emerging as the EU looks beyond its borders (Filtenborg et. al. 2002), using CSOs as agents for pursuing policy goals will be an appealing option for the EU. What makes CSO potentially attractive interlocutors for the EU is that some of these will be particularly susceptible to those aspects of the EU's appeal that makes up its soft power. The EU has long presented itself as a group of nations sharing a commitment to the furthering of democracy, human rights, and the rule of law. It has a strong track record in promoting environmental awareness, and the rule-based Single Market, and the opportunities for free movement that comes with it, adds to its appeal. In this sense the EU is truly shaping perceptions, as Ian Manners (2002) would have 
it, "...not by what it says or does, but by what it is". Many NGOs are staffed with younger people eager to take the opportunities the EU can offer, have a high level of expertise in their fields, have a developed contact network with partners in Western Europe, and are usually very adaptable to changing circumstances (Raik 2006). Thus for some of the CSOs in the Neighbourhood countries that are committed to similar values, the EU can seem to offer an alternative to their own less efficient (or in some cases authoritarian) governments. In this sense the EU seems to be in a position to influence political decisions from below, and become the main partner for organisations working for change. In working from below CSOs are effectively agents of Europeanisation in that they are pursuing a compatible vision of good governance, same as the EU. Thus civil society can contribute to the sort of milieu shaping that the EU typically favours as external relations strategy.

By seeking to strengthen the non-governmental sector in the partner states, the EU will increase the potential number of influence channels in these countries. Creating more networks between people, through not overly political initiatives such as cultural and educational exchange - the latter of which the EU has been working hard to increase through the ERASMUS and SOCRATES programmes can also expose more people in the Neighbourhood countries to European values, an important facet of Nye's soft power concept. These also happen to be fields in which the EU has been relatively successful in engaging Russia, which has been trying hard to get closer integrated in the educational sphere through the Bologna process.

At the same time civil society can be used to put pressure on the partner states' governments, through raising public awareness and through trans-national coalitions, as described in the previous section. Thus while certain aspects of proposed action plans may not immediately appeal to national governments, pressure from below can influence their willingness both to implement what has already been agreed, and to agree to more ambitious targets in the future. Also, by using CSOs as a go-between in securing political objectives, the appearance of direct meddling by the EU in another country can be partly avoided.

While this approach certainly has potential for yielding some of the desired results, it is also not without some significant problems. Some of these are general, relating to the nature of civil society, others are more specific to the Neighbourhood countries. As noted above, CSOs are not always easily controlled. What Warleigh (2001) also discovered in his analysis of British CSOs was, that few of them viewed the EU in more than instrumental terms. Their focus was on better policy outcomes in their particular field, not on furthering the cause of the EU as such. This difference in emphasis between EU institutions and the CSOs which may play a large role in actually implementing the EU's policy objectives should not be lightly dismissed. What's more, there is some evidence to suggest that CSOs may not in fact have much of an 'Europeanising' influence, as most of their members continue to think in national terms, even as some of the professional staffers work intensively with EU officials. At the same time institutional obstacles 
are a regular feature of this relationship. Most of the subsequent list of achievements and failures in pursuing this sort of politics depend largely on the degree to which CSOs are able to accommodate themselves with the given structures.

The state of civil society in Eastern Europe presents important challenges. While acknowledging the role CSOs can play in helping bring reform about, Kristi Raik (2006) lists a number of severe weaknesses that should not be underestimated. In general civil society participation is weaker in the Neighbourhood countries than in Western Europe, and domestic funding sources are often sparse, making CSO either less effective or more dependent on foreign aid. What's more, many of the CSOs most eager to cooperate along the EU's agenda are often seen by the local population as being somewhat aloof, elitist, and narrow in their membership, thus not being representative of society in general. Statements abound to the effect that "civil society cannot be developed from the outside", and what the "the recipients perceive [as] attempts to remake (and not reform) postsocialist societies [is often taken] as an insult [by the local population]" (Narozhna 2004). To some extent this is inevitable, but it should not be underestimated either, that some of the more authoritarian-minded governments in the Neighbourhood countries have consistently tried to portray CSOs as such, or even as stooges for foreign interests, thus generating a significant amount of scepticism towards the motives of these organisations. The so-called 'credibility gap' or inconsistency in EU's external actions is also occasionally a cause for concern. A major source of soft power is also to be seen as actually standing up for the values one claims to espouse. In the case of the EU the gap between rhetoric and reality is often worryingly large, and thus undermines the credibility of the EU as a serious partner (Nielsen 2008). The undermining of EU credibility is observable both for states and for civil society groups in target countries.

Another major obstacle a civil society approach faces is the sheer weight of EU bureaucracy. The long, exhausting processes required in order to gain support and funding can drain the energy from many good projects. In relation to this many CSOs in the target countries have a shortage of people with the necessary language skills and technical expertise to maintain the kind of intensive contacts required with the EU. Periodic attempts by the EU at changing these working procedures, in order to become more flexible and approachable, have not been overly successful.

To some extent the same is true of CSOs in the Neighbourhood countries as in Western Europe, that the contact and cooperation with the EU is seen not merely as ideological reasons but just as much in instrumental terms, as a means to an end. This is not necessarily a problem for the EU as such, though. Many of the reforms being advocated by CSOs and supported by the EU should not primarily be seen as being for the benefit of the EU. Efforts towards democratisation and economic reform have value in and of themselves, and should be pursued for their own sake. Thus while the motivations for cooperation may not always be entirely similar, it seems that where a convergence, even if temporary, exists between the objectives of the EU and CSOs, the EU has the potential, in spite of the inherent 
challenges, for using such approaches, and has been willing to try and make use of them, although, as we shall see in the following, not always successfully.

\section{The activities of Estonian and Russian CSOs in the Europeanisation framework}

The launching of the ENP coincided with Estonia's accession to the European Union in 2004. Since then the Estonian government has enthusiastically embraced the ENP as a major channel for foreign policy initiatives, aiming to help other countries undergo the same transition it has itself been going through since regaining its independence in 1991 (Berg 2005). Estonia has been actively engaged in developmental cooperation since 1998, placing “...ensuring peace, democracy, observance of human rights, economic and social stability and the eradication of poverty in the world as an integral part of Estonian foreign policy" (Principles of Estonian Development Cooperation 2003). Estonia's own reform experiences form the basis for much of the development cooperation initiatives undertaken with partner countries, with Estonia providing expert assistance in handling a transition process. In this the ENP is the major point of reference, with policies being coordinated with the EU. The three countries to which Estonia has devoted most attention in recent years are Georgia, Moldova and Ukraine, which are all three currently undergoing some of the same processes that Estonia went through in the 1990s. Although Russia is not content to be one of several countries covered by one EU policy, as was envisaged by the original Commission policy paper from 2003, the so-called 'Strategic Partnership' covers largely the same range of topics as that of the ENP, and the EU funding instrument for projects under the Strategic Partnership is the same ENPI as for the ENP. Russia would therefore potentially qualify as a target country.

In its stated objectives the Estonian Ministry of Foreign Affairs (MFA) explicitly acknowledges the role played by civil society organisations in both formulating and implementing developmental aid policies. The Developmental Cooperation Roundtable, which the MFA set up, is an umbrella organization for all interested civil society organizations in Estonia, thus providing access for NGOs to the policy process. The involvement of the voluntary sector has been strong in recent years; in 2003, NGOs implemented 7 MFA financed projects out of 13, in 200411 projects out of 16, and in 200510 projects out of 19. As more money for such projects is becoming available, this trend looks set to continue (Estonian Action Plan for Development Cooperation and Humanitarian Aid 20062010). Interestingly, Estonian CSOs see their own role as being pivotal in ensuring good cooperation between the EU and the governments of the ENP countries by being able to act as mediators. In case of serious disagreement, it could even be CSOs directing the entire ENP. "This process should be governed by civil society organizations and not governments", as Florent Sebban from EUROSTEP put it (Open Estonia Foundation Press Release 22/5/2007). 
For a range of historical reasons, Estonian-Russian relations have been rather tense on the governmental level since Estonia re-gained its independence in 1991 (Viktorova 2006). The discourses employed by leading politicians in both countries have tended to heighten tension rather than reducing it, playing on mutual suspicions rather than trying to overcome them. This has often acted as a block to deep cooperation and developing of ties between the two countries, to the detriment of border regions in particular, as their interests are not the same as those of the central governments. This, however, only serves to illustrate the point, made above, about the benefit of being able to establish contacts at lower levels than the state one. In fact, on a lower level a range of initiatives have been taken by CSOs to increase contact and cooperation. ${ }^{2}$ Among the most successful ventures so far have been environmental policy initiatives in the border areas, where Estonian and Russian partner organisations have developed several joint projects (see e.g. Eesti Looduse Fond, www.elfond.ee, and the Peipsi Centre for Transboundary Cooperation, www.ctc.ee). Since some Estonian CSOs in Estonia have few direct contacts in the Neighbourhood countries, many mobilised into cross-border cooperation through Pan-European or Pan-Baltic networks aiming at promoting environmental protection on a regional level; the priorities in such projects were usually set by the organisational headquarters, to which they belonged. In the case of the Estonian-Russian border area most of the regional initiatives are connected to environmental protection in the Baltic Sea Area Coalition Clean Baltic, Taiga Rescue Network, WWF, etc.

The environmental field is naturally easier for establishing cooperation, as its technical nature tends to make it less politically controversial, and the benefits are more obvious than in many other potential areas for cooperation. To give an example, the Swedish Environmental Protection Agency (SEPA) initially intended to develop cross-border cooperation together with Estonian and Russian state agencies and regional administrations. Prior to 1997, however, there were no intergovernmental agreements on environmental protection or transboundary water management between the two countries; the state agencies simply did not have the mandate to develop such intergovernmental cooperation. Thus SEPA turned to an NGO, the Peipsi Centre for Transboundary Cooperation, which at that time was implementing its own research projects across the border, using mostly private funds from U.S. foundations. Such type of cooperation continued until 1997, when the Estonian-Russian transboundary water agreement was signed and an intergovernmental commission was established. Since then, Peipsi CTC and its Russian counterparts - the Pskov-based NGO Chudskoye Project, and CTC St. Petersburg - have become involved in specific projects as project implementation units for both governments.

2 Cooperation between CSOs can, however, be rather vulnerable to the fluctuations in bilateral state relations. When tensions rose dramatically in April 2007, over the removal of the Bronze Soldier Monument in Tallinn, it affected cooperation to the extent that several meetings had to be cancelled. Not because the activists in the organisations wished to, but out of fear of provocations by nationalist elements on both sides. 
The same goes for economic cross-border cooperation, another field which has seen increasing activity. As far back as 2003 the Danish government extended financial support for the establishment of the Pechorskii Business Center, which had the explicit aim of developing cross-border cooperation, not least in cooperation with CSOs (Pechorskaya Pravda 23/9/2003). CSOs have also been able to shape much of the debate on development of cross-border cooperation through holding seminars and roundtables. The European dimension of crossborder cooperation, and its impact on the economic life of the Pskov Oblast is generally acknowledged at these kind of events (Nevskoye Vremya 28/5/2004). Through the TACIS programme the EU has been particularly active in dispensing funding to several such projects in the Russian border regions (Znamya Truda 27/10/2006). Funding has been forthcoming to both business and cultural projects.

An interesting finding in analysing the media coverage of cross-border cooperation is that the Russian media is generally far more aware than their Estonian counterparts of the role the EU is playing in energising the voluntary sector. Thus Russian local and regional newspapers from border areas have in recent years published a fair number of stories of projects which have been carried out by either Russian local authorities or by Russian CSOs in partnership with organisations from other countries using EU funding. What's more, the general tone of the press coverage has tended to be rather positive towards this kind of cooperation. This would suggest that at least to some extent a European dimension is present in the activities of Russian CSOs. Whether this is an instrumental linkage, as Warleigh suggests is true for British CSOs, remains to be seen. At least it can be ascertained that CSOs on both sides of the border have been active in securing funding for their projects. That would suggest that the EU has managed to direct part of their attention towards Brussels - creating new linkages, in effect creating some kind of Europeanisation in Russia. That does not mean, though, that Russian CSOs themselves are in much direct contact with Brussels, or feel themselves very well informed about EU policies in their fields. Interviews reveal that Russian CSOs do not have much experience in cooperating with EU institutions. Rather, they tend to rely on their partners from EU countries for relevant information. On the other hand, this tendency does suggest that the selfperception of Estonian CSOs of acting as the link between the partners and the EU is not completely far-fetched.

Related to this is a field of activity by Estonian CSOs, which, to Russian eyes, is far more controversial than environmental protection, economic development and cultural exchanges. This is the promotion of democratisation and human rights protection in countries such as Belarus and Ukraine, which Russia has traditionally considered its sphere of influence (or 'Near Abroad'). In the case of Ukraine, Estonian CSOs have worked with the Ukrainian government in promoting reforms. In the case of Belarus, one can see CSOs working against the aims of the local regime of Aleksandr Lukashenka. Following the successful campaign for Estonian EU accession, the Estonian European Movement started to look for new opportunities to restructure their previous activities. When the ENP was launched 
the International European Movement asked its Estonian branch to develop contacts with relevant CSOs in Belarus, where the opposition was being strangled by the Lukashenka regime, and at the same time start raising awareness in Estonia about the situation in Belarus (interview with Mr. Aivar Roop, Estonian European Movement). Among the activities, funded by the IEM, has been training for democracy activists from local organisations, and assistance with information campaigns. In this kind of activities an NGO from an EU member state can often act as a more 'acceptable' partner for local movements, taking on a role which the EU itself or a national government from a member state might not as easily be able to fulfil, as their active, direct participation might be seen as untimely interference. Thus while the EU has on the 'macro' or high politics level been considered by some as conducting a policy of 'strategic non-engagement', by not making serious attempts at changing the behaviour of the regime through active engagement (Klinke 2007), it can at the same time be seen on the 'micro level' as attempting to empower civil society to effect changes, recognising that change will ultimately have to come from within.

In pursuing these goals, CSOs from Estonia are clearly better placed than organisations from many Western European countries might be. The shared history Estonia has with the Eastern CIS countries, and the similar experiences of the Soviet occupation and the subsequent transition towards democracy and market economy, gives a quite unique understanding of the issues faced in these countries, and a better ability to empathise and understand the needs in the target area. They are also well placed to act as intermediaries between civil society groups in the Eastern CIS countries and the Commission in Brussels: Having shared experiences and understandings of both background and situation with the former, as well as the expertise and experience necessary for fulfilling the burdensome requirements of the latter.

This only suggests, however, that the EU is indeed pursuing a very deliberate strategy of activating civil society in the Neighbourhood countries, and relying on the best-placed actors to accomplish the aims hoped for. In the fields mentioned, Estonian CSOs have good potentials of fulfilling the role of agents of Europeanisation, promoting certain values, even against the wishes of some of the governments (the Lukashenka regime) of these countries. However, as pointed out by Raik (2006), there is a gap between rhetoric and practice of EU support to civil society. While the European Commission and other European institutions declare the doors open for the CSOs' participation in the ENP implementation, the possibilities for the real participation are fairly limited. CSOs, it appears, are usually not involved in the preparation of EU policies, especially the ENP. As a matter of fact, official positions are drafted by government officials from EU member states and partner countries in intense cooperation with EU institutions, usually leaving the CSOs as mere bystanders. CSOs will typically demand stronger emphasis on political priorities, such as conflict resolution, human rights and democracy, thus articulating more normatively based positions. The European Commission tends to maintain the more pragmatic line that the aim of the ENP is 
not to impose policies, but to follow mutually-agreed Action Plans between the European Commission and the governments of the ENP countries (Euractiv, $7 / 2 / 2007)$. This would seem another example of diverging priorities between the EU and the civil society sector it supposedly tries to engage.

In addition, in EU policy implementation both Estonian and Russian CSOs are treated on the same level as other actors - government agencies, local and regional authorities. Unlike state agencies, NGOs do not receive funding from their states to sustain offices and staff; a majority of those organisations working on crossborder cooperation projects are project-based. Involvement in EU programmes, such as the European Neighbourhood Policy Instrument, requires professional administrative and financial personnel. Otherwise, it is impossible to comply with the EU programmes' reporting, especially audit, requirements. Therefore, the EU programmes are tailored to the needs and capabilities of state or other official organisations and tend not to consider the needs and specifics of NGOs.

Finally it should be mentioned that the bureaucratic character of the EU funding mechanisms form an obstacle to a more inclusive approach in the view of CSOs. Project implementation requires excessive amounts of paperwork to be done by professionals. When projects end, the results of those projects usually cannot be sustained as most CSOs are project-based organisations without additional funding to retain project managers on a permanent basis. Problems also occur when EU fund allocations are delayed, thus making the existence of financial resources a prerequisite for CSOs, prior to the approved implementation costs. More often than not, working CSOs are too small, and without sufficient resources to satisfy such requirements, and many potential projects thus go unrealised. In the Russian context it is hard to imagine the Kremlin being worried about the potential impact that civil society mobilisation can have on the 'sovereign democracy' experienced so far in Russia. Not that the Kremlin takes any chances on this point; using a range of bureaucratic means many Westernminded NGOs, or those receiving Western funding, have been shut down by the authorities (Lucas 2008).

\section{Conclusion}

Using CSO as agents in foreign policy is potentially a very attractive way of approaching problems, bringing to bear a range of capabilities that states or similar actors would often find difficult. It is therefore an important addition to the traditional ways of diplomacy. At the same time, as outlined in the previous sections, there are also a number of potential downsides to such a strategy, which should not be underestimated.

For the EU, pursuing a strategy of engaging with CSOs in order to follow its overall goals, fits well with its soft power based approach of milieu-shaping through slow institutionalisation. As practised through the ENP and the Strategic Partnership this emphasises the importance of civil society, and of partnership and 
dialogue between partners. The EU has generally attempted to make use of the resources available in partner countries, thus by-passing to some extent the traditional foreign policy agendas.

But although attractive and in keeping with the EU's traditional modus operandi the policy is not entirely unproblematic. Civil society in the Neighbourhood countries remains weak compared to Western Europe, and the civil society sector is still fragmented and somewhat open to pressure. The partner organisations clearly push their own agendas at the same time as implementing the EU's agenda, and the socialisation effect that is supposed to spring from this cooperation is not always clear. At the same time cooperation between national based CSOs in the partner countries and supranational institutions in Brussels is also occasionally made more difficult by EU bureaucracy, and when coming up against less than positive popular attitudes towards such cooperation, often stoked by undemocratic regimes. The Estonian-Russian experiences in civil society cooperation show examples of both these dynamics.

Looking at the activities of Estonian and Russian CSOs working under the Europeanisation framework, it is clear that a number of projects attempting to further the EU's goals are taking place across the EU's outer border. Some of these projects are in fields where the EU could be expected to face trouble acting on its own. In effect, the EU is trying to influence the course of events in its partner countries 'from below'. Whether this will in the longer term lead to a real 'Europeanising' effect is too early to say given the institutional and structural obstacles outlined in this article, but the mere presence of an ongoing process might suggest that CSOs working together under the EU umbrella may gradually help foster the improved relations between Estonia and Russia, which the two national governments seem so unwilling to bring about.

\section{Acknowledgements}

This article presents findings of the EUDimensions Project (contract no. CIT5028804), which ran from 2006 to 2008 and investigated civil society cooperation across the EU's outer borders. More about it, see http://www.eudimensions.eu/ index.htm.

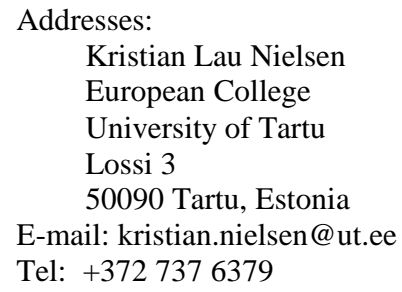


Eiki Berg

Institute of Government and Politics

University of Tartu

Ülikooli 18

50090 Tartu, Estonia

E-mail: eiki.berg@ut.ee

Tel.: +3727375583

\section{Gulnara Roll}

Institute of Government and Politics

University of Tartu

Ülikooli 18

50090 Tartu, Estonia

E-mail: gulnara.roll@ut.ee

Tel.: +372 7375583

\section{References}

Alibioni, Roberto (2005) "The geopolitical implications of the european neighbourhood policy". European Foreign Affairs Review 10, 1-16.

Berg, Eiki (2005) "Prioritizing the east in Estonia: chances to become a good advocate, honest broker or reliable supervisor?". In Enlarged EU - enlarged neighbourhood: perspectives of the European neighbourhood policy, 243-258. Nicolas Hayoz, Leszek Jesien, and Wim van Meurs, eds. (Interdisciplinary Studies on Central and Eastern Europe, 2.) Bern: Peter Lang.

Communication from the Commission to the Council and the European Parliament on Strengthening the European Neighbourhood Policy, COM (2006)726 final, Brussels, 4. December 2006.

Dannreuther, Roland (2006) "Developing the alternative to enlargement: the European neighbourhood policy". European Foreign Affairs Review 11, 2, 183-201.

Estonian Foreign Office (2003) Principles of Estonian development cooperation. Riigikogu Resolution of 15 January 2003, http://www.vm.ee/eng/kat_178/3815.html

Estonian Foreign Office (2006) Eesti arengukoostöö ja humanitaarabi arengukava 2006-2010. [Estonian Action Plan for Development Cooperation and Humanitarian Aid 2006-2010] http://web-static.vm.ee/static/failid/219/AH_strateegia_2006-2010.pdf

Euractiv (2007) NGOs ask for greater say in EU 'neighbourhood' policy. (7/2). http://www.euractiv.com/en/enlargement/ngos-ask-greater-eu-neighbourhood-policy/article161482

European Commission (2004) European neighbourhood policy strategy paper. Brussels.

Filtenborg, Mette Sicard, Stefan Gänzle, and Elisabeth Johansson (2002) "An alternative theoretical approach to eu foreign policy: 'network governance' and the case of the northern dimension initiative". Cooperation and Conflict 37, 4, 387-407.

Gray, Emily and Paul Statham (2005) "Becoming European? The transformation of the British promigrant sector in response to Europeanization". Journal of Common Market Studies 43, 4 $877-898$

Hyde-Price, Adrian (2006) "Normative' power Europe: a realist critique”. Journal of European Public Policy 13, 2, 217-234.

Keohane, Robert O. and Joseph S. Nye (1977) Power and interdependence: world politics in transition. Boston: Little, Brown.

Klinke, Ian (2007) "The European Union's strategic non-engagement in Belarus: challenging the hegemonic notion of the EU as a Toothless Value diffuser" Perspectives 27, 25-43.

Lavenex, Sandra (2004) "EU external governance in 'wider Europe"'. Journal of European Public Policy 11, 4, 680-700. 
Lucas, Edward (2008) The new cold war: how the Kremlin menaces both Russia and the west. London: Bloomsbury.

Manners, Ian (2002) "Normative power Europe: a contradiction in terms?". Journal of Common Market Studies 40, 2, 235-258.

Manners, Ian (2008) "The normative ethics of the European Union".International Affairs 84, 1, $45-60$.

Marchetti, Andreas (2006) "The European neighbourhood policy: foreign policy at the EU's periphery". (Discussion Paper, C158.) Bonn: Zentrum für Europäische Integrationsforschung.

Michalski, Anna (2005) 'The EU as a Soft Power: The Power of Persuasion' in Melissen, Jan (Ed.) The New Public Diplomacy: Soft Power in International Relations. PalgraveMacMillan. London.

Narozhna, Tanya (2004) "Foreign aid for a post-euphoric eastern Europe: the limitations of western assistance in developing civil society". Journal of International Relations and Development 7, 3, 243-266.

Nielsen, Kristian L. (2007) "Opportunities and limitations for the Baltic states in the EU-Russia strategic partnership". Baltic Security and Defence Review 9, 109-130.

Nielsen, Kristian L. (2008) "The weakness of the EU's soft power strategy". Paper presented at the ECPR Standing Group on the European Union Fourth Pan-European Conference on EU Politics, University of Latvia, Riga, 25th-27th of September 2008.

Nye, Joseph S. (2005) Soft power: the means to succeed in world politics. New York: Public Affairs.

Open Estonia Foundation (2007) "Georgia, Moldova and Ukraine call Estonia for more active development cooperation". Press release, http://www.oef.org.ee/_news/et/press/2007-0522 103954/

Radaelli, Claudio M. (2000). "Whither Europeanization? Concept stretching and substantive change". European Integration online Papers (EIoP) 4, 8, available at http://papers.ssrn.com/ sol3/papers.cfm?abstract_id $=302761$

Raik, Kristi (2006) "Promoting democracy through civil society: how to step up the EU's policy towards the eastern neighbourhood". CEPS Working Paper 237, February.

Ringius, Lasse (1997) "Environmental NGOs and regime change: the case of ocean dumping of radioactive waste”. European Journal of International Relations 3, 1, 61-104.

Sending, Ole Jacob and Iver B. Neumann (2006) "Governance to governmentality: analyzing NGOs, states and power". International Studies Quarterly 50, 3, 651-672.

Toje, Asle (2005) "The European security strategy: a critical appraisal". European Foreign Affairs Review 10, 117-133.

Viktorova, Jevgenia (2006) "Transformation or escalation? The Estonian-Russian border conflict and European integration”. EU Border Conflict Studies Working Paper (Birmingham) 21.

Walters, William (2004) "The frontiers of the European Union: a geostrategic perspective". Geopolitics 9, 3, 674-698.

Warleigh, Alex (2001) "'Europeanizing' civil society: NGOs as agents of political socialization”. Journal of Common Market Studies 39, 4, 619-639. 